\title{
BANCO DE OLHOS
}

\author{
EYE BANK
}

Sidney Júlio de Faria e Sousa ${ }^{1} \&$ Stella Barretto²

Docente $^{1}$ do Departamento de Oftalmologia e Otorrinolaringologia; Ortoptista ${ }^{2}$ - Coordenadora do Banco de Olhos do Hospital das Clínicas - Faculdade de Medicina de Ribeirão Preto da Universidade de São Paulo.

CORRESPONDÊNCIA: Departamento de Oftalmologia e Otorrinolaringologia da Faculdade de Medicina de Ribeirão Preto - Campus Universitário - CEP: 14048-900 - São Paulo - SP. Fax: (016) 633-0186.

FARIA e SOUSA SJ de \& BARRETTO S. Banco de Olhos. Medicina, Ribeirão Preto, 30: 97-99, jan./mar. 1997.

RESUMO: Banco de Olhos visam captar, armazenar e distribuir córneas, minimizando a possibilidade de transmissão de doenças através do transplante. O controle de qualidade do tecido é feito com o exame à Lâmpada de Fenda, análise do sangue e do prontuário médico do doador morto. A vitalidade do enxerto depende, fundamentalmente, da vitalidade do endotélio. Essa, por sua vez, varia com vários fatores, tais como: a idade do doador, o tempo entre a morte e a preservação do tecido, cirurgias prévias, etc. Além dos óbvios benefícios ao receptor, o ato da doação facilita a recuperação familiar do trauma da perda do ente querido.

UNITERMOS: Bancos de Olhos. Transplante de Córnea.

A luz penetra no olho e incide sobre a retina, onde é transformada em impulsos nervosos. Esses impulsos são levados ao cérebro para a interpretação das informações. Para que essa cadeia de eventos se realize, é necessária a integridade dos meios transparentes do olho, ou seja, da córnea, do cristalino e do humor vítreo.

Opacificações em quaisquer de uma dessas estruturas podem afetar a visão. As opacidades do humor vítreo resultam, frequientemente, de hemorragias intra-oculares que tendem a resolução espontânea. As opacidades do cristalino formam as cataratas, cujo tratamento envolve a retirada cirúrgica da estrutura.

Indica-se o transplante somente quando a opacidade se situa na córnea. Tais opacidades variam desde as anormalidades congênitas até as seqüelas das úlceras infecciosas.

O transplante consiste na substituição de uma área de córnea doente por córnea sadia de cadáver. $\mathrm{O}$ transplante de córnea, é dentre os transplantes, o que melhores resultados oferece, tanto a curto como a longo prazo. A rejeição é infreqüente e, quando ocorre, é facilmente revertida com colírio de corticóide. A imunidade não precisa ser deprimida para que o enxerto se mantenha sadio. Essa característica, única da córnea, parece estar relacionada ao fato de ela não ter vasos sangüíneos. Nem mesmo os testes de histocompatibilidade, tão importantes em outros transplantes, são necessários. Estima-se que, em cada dez pacientes transplantados, sete tem sucesso definitivo. Além disso, o procedimento pode ser repetido. O número de repetições nãoé, no entanto, ilimitado. Cada cirurgia tende a danificar um pouco o olho de modo a tornar os enxertos subseqüentes menos viáveis.

Afora a rejeição, outro fator determinante do sucesso do transplante é a integridade das células endoteliais. Essa camada, que reveste a face interna da córnea, tem a função de manter a transparência da mesma. Através de um mecanismo de transporte de eletrólitos, ela mantém a córnea enxuta e transparente. As células endoteliais não regeneram em número 
significante, e vão diminuindo com o envelhecimento. Os espaços deixados pelas células que morrem são preenchidos por células vizinhas que se hipertrofiam. É por isso que a córnea de uma pessoa jovem tem maior chance de manter a transparência do que a de uma pessoa idosa. Outros fatores também concorrem para o decréscimo do número de células endoteliais. Eles incluem: o tempo entre a morte e a retirada do olho, o tempo entre a retirada do olho e o transplante, permanência prolongada do doador em tratamento intensivo e, até mesmo, a temperatura do ambiente onde se encontra o cadáver. A simples colocação de compressas geladas sobre os olhos do falecido, aumenta significativamente a viabilidade do endotélio. É que o frio diminui a velocidade das reações de decomposição do tecido. No entanto, independentemente dessas considerações, o Banco aceita qualquer doação. Em vez de meras suposições quanto a qualidade do tecido, ele decide sobre o uso ou não dos mesmos, através do exame do tecido.

Com a intenção de prolongar a sobrevida das células endoteliais, foram desenvolvidas técnicas de preservação da córnea que mantém a vitalidade do tecido de dois a quinze dias. Essas técnicas variam desde a "Câmara Úmida" até a sofisticados meios de cultura celular e criopreservação. Na verdade, a criopreservação pode manter a viabilidade do tecido por tempo ilimitado.

A maioria dos Bancos de Olhos solicita o olho e não apenas a córnea. A lógica dessa atitude é que, em laboratório, as condições são muito mais apropriadas para a retirada da córnea. O globo ocular, por exemplo, pode ser banhado com solução de antibiótico, o que não pode ser feito com a córnea livre pois o endotélio morreria. Além disso, a córnea pode ser retirada em condições assépticas e sem pressa. Sua análise, à Lâmpada de Fenda, é mais fácil e precisa. A esclera pode ser aproveitada como material de reconstrução, em cirurgias plásticas. Os olhos não apropriados para cirurgias podem ser utilizados no treinamento cirúrgico de residentes e pesquisa. Com as atuais técnicas de reconstrução orbitária, o semblante do cadáver permanece inalterado, como se os globos oculares não tivessem sido retirados.

Uma grande preocupação do Banco de Olhos é a de minimizar a possibilidade de transmissão de doenças ao receptor. Para tanto, é rotina fazer-se análise pormenorizada do prontuário médico, bem como análise laboratorial do sangue do cadáver. São exemplos típicos de doenças potencialmente transmissíveis pela córnea: AIDS, Hepatite B, Raiva e a Doença de Creutzfeldt-Jakob. Excluindo-se essas patologias, todas as outras são, em princípio, aceitas e, depois, selecionadas pelo Banco de Olhos. A introdução de germes patológicos externos ao enxerto, durante o procedimento da enucleação, preparo da córnea e transplante, é minimizada com a adesão rigorosa às técnicas de assepsia. Isso significa que, em todos esses procedimentos, são utilizados gorros, máscaras, aventais, luvas, campos e instrumentos estéreis. Não é necessário, no entanto, sala cirúrgica para a realização da enucleação. Como precaução adicional, o olho enucleado é banhado numa solução de antibióticos, por dez minutos, logo após a retirada.

Do ponto de vista prático, o sucesso de um programa de transplantes depende do número de doações. Existem basicamente duas estratégias de obtenção da doação: os cartões de doação e os programas hospitalares.

Os cartões de doação visam encorajar as pessoas a se tornarem doadoras em potencial. Eles são benéficos por duas razões: primeiro, porque constituem uma fonte potencial de doações de órgãos; segundo, porque funcionam como instrumento de educação pública, mantendo viva a importância social da doação. A desvantagem é que os membros das famílias pesarosas, freqüentemente esquecem de comunicar a morte. Os Bancos de Olhos que funcionam exclusivamente com cartões de doação, geralmente apresentam um desempenho pobre.

Os programas hospitalares visam o estabelecimento de um relacionamento de trabalho com os hospitais, para que seus membros participem das solicitações de doações. A participação do Banco de Olhos pode ser ativa ou passiva.

Na primeira, sempre que um paciente morre em um hospital, alguém desse hospital procura a família para pedir a doação. Essa pessoa pode ser um médico, uma enfermeira ou mesmo um capelão. O método é chamado passivo, porque o Banco não participa da obtenção da doação. Ele depende inteiramente da boa vontade do pessoal hospitalar. Por isso, ele é raramente eficiente, uma vez que esses profissionais, freqüentemente, esquecem de abordar as famílias em virtude do acúmulo de trabalho a que estão submetidos. Contribui para a falha, a falta de treino em se lidar com a situação. Na segunda, alguém do hospital comunica o Banco de Olhos sobre a morte. Este envia um funcionário treinado para conversar com a família. A prática tem demonstrado que o número de doações aumenta consi- 
deravelmente, quando o pedido de doação é feito por pessoa que consegue tranqüilizar a família do falecido.

Finalmente, seja qual for o método utilizado na obtenção das doações, nenhuma informação sobre os critérios de seleção do doador deve ser fornecida ao hospital. A direção deve ser informada que todos os pacientes que morrem servem como doadores de olhos. Quando esses critérios são revelados, tanto o corpo médico quanto a enfermagem tendem a ser exageradamente conservadores na seleção do doador.
Além disso, se a obtenção de tecidos for limitada aos casos de transplantes, não haverá órgãos suficientes para o treinamento cirúrgico e pesquisa. Muito se insiste nos benefícios da doação sobre o receptor. O que freqüentemente se esquece é que o ato da doação é extremamente reconfortante à família do doador. A longo prazo, a família percebe que, pelo fato de ter permitido a doação, ela expressou sua religiosidade no mais alto grau, e que isso, de alguma forma, aproximará seu ente querido da companhia divina.

FARIA e SOUSA SJ de \& BARRETTO S. Eye Bank. Medicina, Ribeirão Preto, 30: 97-99, jan./march 1997.

ABSTRACT: Eye Banks are responsible for the procurement, storage and distribution of corneas with minimum risk of transmission of diseases through the transplantation. The quality control of the tissue is done by Slit Lamp, blood analysis and study of the medical file of the donor. The vitality of the graft depends on the vitality of the endothelium. This varies with many factors as: age of the donor, death-preservation interval, previous surgeries and so on. Besides the obvious benefits to the receptor, the act of donation eases the recuperation of the familial grievance.

UNITERMS: Eye Banks. Corneal Transplantation.

\section{BIBLIOGRAFIA CONSULTADA}

1 - FARGE EJ. Eye banking, 1944 to the present. Surv Ophthalmol 33: 260-263, 1989.
2 - KING J H Jr. Eye bank programs. Am J Ophthalmol 54: 5-7, 1962.

Recebido para publicação em 03/01/97

Aprovado para publicação em 30/01/97 